\title{
Coral Community: Preliminary Biodiversity Survey of Churna Island, Northern Arabian Sea
}

\author{
Shahid Amjad ${ }^{1}$ Nuzhat Khan ${ }^{2 a}$ Saira Ishaq ${ }^{2 b}$ \\ RECEIVED ON 28.01.2019, ACCEPTED ON 03.05.2019
}

\begin{abstract}
Biodiversity survey between Cape Monze and Churna Island was carried out for the assessment of coral assemblages in the area. During the present study, diving surveys were conducted to document the living corals that included deep sea coral, Coelenterates, Bryozoans, Gorgonia (Sea Fan), Scleractinian, (Stony Corals) Cnidaria (Hydroids), Porites (Small Polyp Stony), Pocilopora (Cauliflower Corals), Acropora (Hard Corals), sea urchins, sea anemones, coral fish spp, sea slugs, stone fish and bivalves were observed and documented. To have a better understanding of the distribution pattern "Shannon Weiner Biodiversity Index" for species diversity " $\mathrm{H}$ " $(0.845-1.176)$ and evenness " $J "(0.962-0.937)$ were calculated, the values indicate that the coral species were evenly distributed and did not show any significant variation in the area.
\end{abstract}

Budding coral communities were observed at the sedimentary rock of Churna in patches, and showed a random distribution behavior all along the surveyed area. Random, scattered and aggregate distribution patterns of corals may be due to the wave beaten physical environment of Churna Island that do not allow sustainable growth of coral communities. Moreover, the high energy waves and water currents destablize and erode the sedimentary substrate on which corals grow. The corals are therefore unable to establish themselves to form a natural reef due to loss of natural living and non-living substrate.

The ecology of Churna Island also under the influence of nearby coastal industries, and the Hub River influx causing floods in the SW monsoon period that may destablize rubble and increase the seawater turbidity level. These environmental factors contributing to the deterioration of present day corals, and larval settlement.

It may be concluded that biological resources are renewable and can even increase with proper management techniques. Breakwater wall and artificial substrate must be encouraged to further facilitate the growth and development of Corals in the area.

Keywords: Churna Island Ecosystem, Marine Benthic Invertebrates, Management Strategy.

\section{INTRODUCTION}

The coastline of Pakistan is approximately $1,000 \mathrm{~km}$ long, it encompasses two distinct zones, the Sindh coast and Makran coast along Northern Arabian Sea (Fig. 1). Makran coast is about $730 \mathrm{~km}$, extending from mouth of the Hub River in the east to Jiwani in the west [1]. The cliffs, rocky head-lands, sand dunes, lagoons and mangroves marsh are the main features of the area. The Balochistan Coastal Area represents significant ecological value due to its biological diversity including coral colonies of Churna, (Lasbela), Astola Island (Off -Pasni) and Gwadar [24]. Coral reef structures over long periods of time

\footnotetext{
${ }^{1}$ Department of Environment and Energy Management, Institute of Business Management (IoBM), Karachi. Email: shahid.amjad@iobm.edu.pk

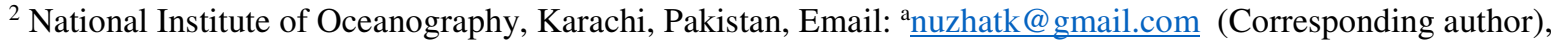
bishaqsaira@hotmail.com

This is an open access article published by Mehran University of Engineering and Technology, Jamshoro under CC BY 4.0 International License. 
make them the largest and oldest living ecological systems on earth [5]. The physical structure of the Island is composed of sandstone, shale and mudstone, hosting sensitive habitat including corals, exotic fish etc, and the island is a popular location for SCUBA diving and snorkeling. Churna Island has also been proposed as MPA (Marine Protected Area) due to its ecological significance.

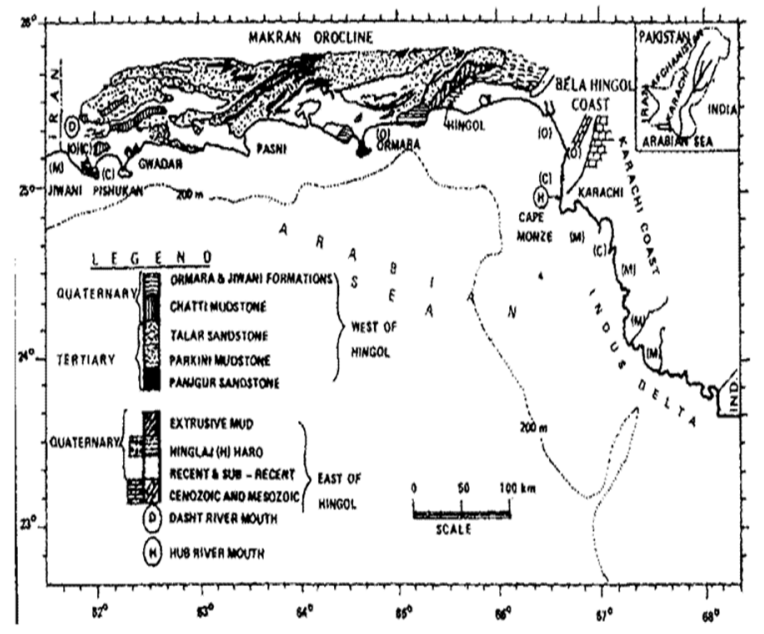

FIG. 1. COASTAL AREA OF PAKISTAN (UN ESCAP 1996)

The area is located in open sea environment where the high energy waves and water currents influence the ecology of the area. The physical characteristics of the coastal area may hamper sustained growth of coral communities. The ecology of Churna Island is continuously under the influence of discharges from nearby coastal industries and Hub River discharges. These environmental conditions may have contributed to the deterioration of corals and larval settlement on Churna Island. It was reported that tropical coral reefs can grow at rates of 1-100 $\mathrm{cm} /$ year upwards [6]. Coral growth and development is a cooperative and a symbiotic, venture. The coral reefs (polyp) provide shelter and food to marine macro algae that is in the form of nutrients. Whereas, the polyp also gets life support in return from the algae via photosynthesis. The process of photosynthesis convert micronutrients into organic food in the presences of sunlight, it is therefore tropical corals grow in shallow and clear sea. The small marine algae or/and zooxanthellae growing inside polyps of tropical coral, in higher temperatures marine algae also give corals their color [7]. It is also reported that in reduced dissolved oxygen conditions the algae become stressed and leave the polyp, this is due to the symbiotic venture between corals polyp and marine microalgae that come under stress due to anoxic conditions. It is also documented that change in seawater temperature rise may lead to coral bleaching and it is therefore corals are known to be indicator of climate change [8].

Coral reefs are biologically rich zones of coastal areas it vital to coastal fisheries. These areas also support exotic tropical fish and variety of BMI (Benthic Marine Invertebrates), marine macro and meiofauna. It provides spawning and nursery ground of commercially important fisheries, shelter and feeding areas of huge variety of organisms that included economically important crustaceans such as shrimps, spiny lobsters and crabs and cephalopods like octopus, squids and cuttlefish. Thus, coral reefs support livelihood for local communities as well as providing revenue for national fishing fleets [9]. The purpose of this paper is to provide a greater understanding of the budding coral community its associated benthic invertebrate fauna at Churna Island and suggest some techniques for coral management

\section{METHODOLOGY}

\subsection{Study Area}

Churna Island was selected for the present marine ecological surveys. The Island is approximately 1.2 $\mathrm{km}$ long and $0.5 \mathrm{~km}$ wide located about $9 \mathrm{~km}$ west of the mouth of the Hub River between Balochistan and Sindh Coast. The physical structure of Island is composed of sandstone, shale and mudstone, hosting sensitive habitat including corals, exotic fish. It is also a popular site for SCUBA diving and snorkeling activity. Churna Island is also proposed as MPA due to its ecological significance. Within the close vicinity of Churna Island. Five sampling station were identified in closed proximity of Churna Island in approximately 8-10 m depth contour. 2-stations C 1 and $\mathrm{C} 2$ were coral diving stations, and three station $\mathrm{M}$ 1, M 2 and M 3 were Marine benthic stations (MBI) at sampling depth ranging from 6.0-17.5 m. Depth for marine benthic invertebrates, and two for assessment of coral community (Table 1, and Fig. 2). 


\begin{tabular}{|c|c|c|c|c|c|}
\hline \multicolumn{6}{|c|}{$\begin{array}{l}\text { TABLE } 1 \text { SAMPLING LOCATIONS FOR } \\
\text { MARINE BENTHIC INVERTEBRATES }\end{array}$} \\
\hline $\begin{array}{l}\text { MBI } \\
\text { Stati } \\
\text { ons }\end{array}$ & $\begin{array}{c}\text { Latit } \\
\text { ude } \\
\mathrm{N}\end{array}$ & $\begin{array}{l}\text { Longi } \\
\text { tude } \mathrm{E}\end{array}$ & Depth & $\begin{array}{l}\text { Bottom } \\
\text { substrat }\end{array}$ & $\begin{array}{l}\text { Sampling } \\
\text { Date } \\
\text { \&Time }\end{array}$ \\
\hline M-1 & $\begin{array}{l}24^{\circ} 5 \\
5^{\prime} 3.5 \\
6 " \mathrm{~N}\end{array}$ & $\begin{array}{c}66^{\circ} 40^{\prime} \\
51.98 \\
\text { "E }\end{array}$ & $6.0 \mathrm{~m}$ & & $\begin{array}{l}25 / 5 / 2015 \\
1045\end{array}$ \\
\hline M-2 & $\begin{array}{l}24^{\circ} 5 \\
5^{\prime} 12 . \\
86 " \mathrm{~N}\end{array}$ & $\begin{array}{c}66^{\circ} 39^{\prime} \\
12.93 \\
\text { "E }\end{array}$ & $\begin{array}{c}14.0 \\
\mathrm{~m}\end{array}$ & & $\begin{array}{l}25 / 5 / 2015 \\
1005\end{array}$ \\
\hline M-3 & $\begin{array}{l}24 \\
5 ' 2 \\
57\end{array}$ & $\begin{array}{c}66^{\circ} 37^{\prime} \\
34.69 \\
\text { "E }\end{array}$ & $\begin{array}{c}17.5 \\
\mathrm{~m}\end{array}$ & $\begin{array}{l}\text { Mostly } \\
\text { Rocky }\end{array}$ & $\begin{array}{l}25 / 5 / 2015 \\
0915\end{array}$ \\
\hline
\end{tabular}

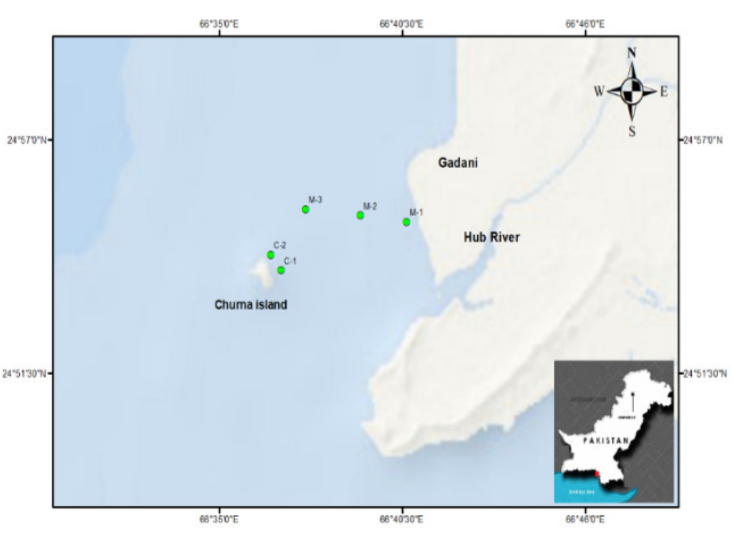

FIG. 2. SAMPLING LOCATION OF MARINE BENTHIC INVERTEBRATES AND CORAL ECOLOGICAL SURVEYS

\section{SAMPLING TECHNIQUES}

\subsection{Marine Benthic Invertebrates}

MBI and coral ecological surveys were undertaken in and around the Churna Island to evaluate the benthic marine ecosystem and the corals in close proximity to Churna Island. The samples for MBI and corals were undertaken on $6^{\text {th }}$ and $25^{\text {th }}$ May 2015, at the onset of SW monsoon period. A $20 \mathrm{~m}$ fiberglass boat installed with GPS (Global Positioning System), Garmin 78SC was used along with a Simrad echo sounder - an accurate marine navigation system was used to collect bottom sediment samples using a Pedal Grab having an overall capacity to collect $280 \mathrm{~cm}^{2}$ of sediments. Undisturbed MBI samples were collected from Churna Island location (Table 1, Fig. 2). The samples were preserved in $10 \%$ formalin and sent to Marine Science Lab for sorting and enumerating the species. The MBI were identified using standard identification sheets and taxonomic keys [10]. Student's t-test, population distribution behavior, variance statistical methods were applied to measure and quantify abundance and distribution.

\subsection{Assessment of Coral Community}

Underwater surveys were undertaken for the assessment of coral community at two dive site in the close proximity Churna Island (Table 2, Fig. 2). Each dive ecologically surveyed approximately $100 \mathrm{~m}$ length by $10 \mathrm{~m}$ wide corridor in a linear direction parallel to the Island coastline. An approximate area of $1,000 \mathrm{~m}^{2}$ was covered at each of the dive locations to evaluate changes in the benthic ecosystem, which included observation of species on the rocky ledges and cleavages at underwater depths ranging from 8-10 $\mathrm{m}$ depth. A $1.0 \mathrm{~m}^{2}$ quadrate was used to evaluate species distribution and abundance. Soft and hard corals growing on rocky substrates and other sessile and sedentary taxonomic groups in rocky crevices were documented and photographed. A hand held GPS was used to identify the exact location of each dive. The subsurface area surveyed was calculated and documented for taxonomic groups and faunal assemblages.

\section{RESULT AND DISCUSSION}

The students' t-test shows that the two coral sampling location $\mathrm{C}-1$ and $\mathrm{C}-2$ were not significantly different ( $p>0.1035)$ at 0.05 level. Species diversity H' $(0.845-$ 1.176) and evenness J' (0.962-0.937) were calculated, the values indicate that the coral species were evenly $(\mathrm{J}$ ') distributed and did not show any significant variation in the area. The Major MBI taxonomic groups identified and mean abundance is given in Table 3. Nematodes and Harpacticoid copepods were by far the most dominant group at sampled stations M1, M-2 and M-3. Nematodes ranged from 130-170 individual per $10 \mathrm{~cm}^{2}$, Harpacticoid, Calanoid copepods, Ostracods, and Cirratulid worms ranged from $40-60$ individuals per $10 \mathrm{~cm}^{2}$.

The dominant MBI groups observed were Tanaidacean, Harpacticoid copepod, Noctiluca sp Polychaete spp, Cirratulid juvenile, Cyclopoid copepodite, Ostracod, showed aggregate distribution, 


\begin{tabular}{|c|c|c|c|c|c|c|}
\hline \multicolumn{7}{|c|}{ TABLE 2. CORAL SAMPLING LOCATIONS AT CHURA } \\
\hline Station No, & $\begin{array}{c}\text { Dive } \\
\text { Depth }\end{array}$ & Latitude N & Longitude E & Survey Area & $\begin{array}{c}\text { Date and } \\
\text { Time }\end{array}$ & Habitat Type \\
\hline C-1 & $10 \mathrm{~m}$ & $24.53 .65 \mathrm{~N}$ & $066.36 .70 \mathrm{E}$ & $\begin{array}{c}\text { Approximately } \\
1,000 \mathrm{~m}^{2} \\
(100 \mathrm{mx} 10 \mathrm{~m})\end{array}$ & $\begin{array}{c}6.5 .2015 \\
1215 \text { Hours } \\
\text { Dive Time } \\
50 \text { Minutes }\end{array}$ & $\begin{array}{c}\text { Rocky/coarse } \\
\text { sand, rubble with } \\
\text { broken shell } \\
\text { fragments }\end{array}$ \\
\hline $\mathrm{C}-2$ & $8.0 \mathrm{~m}$ & $24,54.25 \mathrm{~N}$ & $066.36 .50 \mathrm{E}$ & $\begin{array}{c}\text { Approximately } \\
1,000 \mathrm{~m}^{2} \\
(100 \mathrm{mx} 10 \mathrm{~m})\end{array}$ & $\begin{array}{c}6 . .2015 \\
1330 \text { Hours } \\
\text { Dive Time } \\
45 \text { Minutes }\end{array}$ & $\begin{array}{c}\text { Rocky ledges and } \\
\text { coarse sediments }\end{array}$ \\
\hline
\end{tabular}

\begin{tabular}{|c|c|c|c|c|c|}
\hline Species/Taxa Groups & Variance & Mean & Chi-sq & d.f. & Distribution \\
\hline Tanaidacean & 111 & 10 & 22.2 & 2 & Aggregated \\
\hline Cumacean & 7 & 2 & 7 & 2 & Random \\
\hline Harpacticoid Copepod & 12 & 2 & 12 & 2 & Aggregated \\
\hline Isopod Spp & 1 & 1 & 2 & 2 & \multirow{9}{*}{ Random } \\
\hline Naphtys sp. & 3 & 1 & 6 & 2 & \\
\hline Spionid spp & 1.3333 & 0.6667 & 4 & 2 & \\
\hline Cirratulid spp & 3 & 1 & 6 & 2 & \\
\hline Sabellid Worm & 0.3333 & 0.3333 & 2 & 2 & \\
\hline Terebellid Worm & 0.3333 & 0.6667 & 1 & 2 & \\
\hline Polychaete spp & 7 & 3 & 4.6667 & 2 & \\
\hline Bivalve & 0.3333 & 0.3333 & 2 & 2 & \\
\hline Nematode spp & 430.3333 & 150.6667 & 5.7124 & 2 & \\
\hline Noctiluca sp & 16.3333 & 2.3333 & 14 & 2 & \multirow{2}{*}{ Aggregated } \\
\hline Harpacticoid Copepodite & 397 & 44 & 18.0455 & 2 & \\
\hline Calanoid Copepod sp 1 & 16.3333 & 5.3333 & 6.125 & 2 & \multirow{4}{*}{ Random } \\
\hline Calanoid Copepodite sp 2 & 5.3333 & 4.6667 & 2.2857 & 2 & \\
\hline Nauplii & 9.3333 & 2.6667 & 7 & 2 & \\
\hline Cumacean & 1.3333 & 0.6667 & 4 & 2 & \\
\hline Ostracod & 954.3333 & 18.3333 & 104.1091 & 2 & Aggregated \\
\hline Tanaidacean & 2.3333 & 1.6667 & 2.8 & 2 & \multirow{2}{*}{ Random } \\
\hline Oikopleura & 3 & 1 & 6 & 2 & \\
\hline Cirratulid Juvenile & 40.3333 & 3.6667 & 22 & 2 & Aggregated \\
\hline Cyclopoid Copepodite sp 3 & 52 & 6 & 17.3333 & 2 & Aggregated \\
\hline Kinorhynch & 0.3333 & 0.3333 & 2 & 2 & Random \\
\hline \multicolumn{6}{|c|}{ 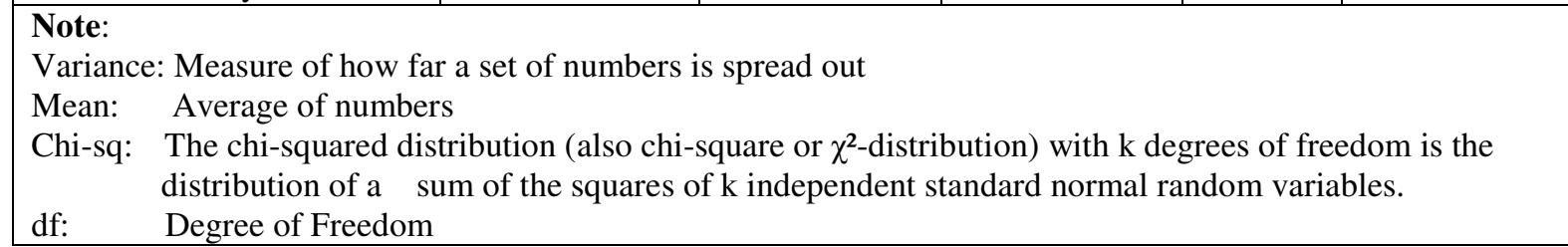 } \\
\hline
\end{tabular}

while the other groups of MBI exhibited random distribution pattern [6]. The MBI's broadcast their reproductive material, these reproduction material and larvae are at the mercy of strong bottom currents. The Coral communities and other benthic macrofauna exhibited a random distribution pattern. The dominant groups observed per $\mathrm{m}^{2}$ are shown in Table 4 .

The Taxonomic groups observed at the Churna dive station $\mathrm{C}-1$ and $\mathrm{C}-2$ show a random distribution mode none of the coral exhibited aggregated behavior. One of the reasons for random distribution is their mode of 


\begin{tabular}{|c|c|c|c|c|c|}
\hline \multicolumn{6}{|c|}{ DISTRIBUTION PATTERN } \\
\hline Taxonomic Groups & Variance & Mean & Chi-sq & df & Distribution \\
\hline Coelentrates & 0.5 & 2.5 & 0.2 & 1 & \multirow{15}{*}{ Random } \\
\hline Bryozones & 2 & 4 & 0.5 & 1 & \\
\hline Gorgonia (Sea Fan) & 2 & 1 & 2 & 1 & \\
\hline Scleractinian & 0.5 & 2.5 & 0.2 & 1 & \\
\hline Cnidaria & 2 & 1 & 2 & 1 & \\
\hline Porites & 4.5 & 3.5 & 1.2857 & 1 & \\
\hline Pocilopora & 2 & 2 & 1 & 1 & \\
\hline Acropora (Star Coral) & 0.5 & 0.5 & 1 & 1 & \\
\hline Sea Urchins & 8 & 2 & 4 & 1 & \\
\hline Coral Fish spp & 8 & 5 & 1.6 & 1 & \\
\hline Macro Algal spp & 4.5 & 2.5 & 1.8 & 1 & \\
\hline Sea Slugs & 0.5 & 0.5 & 1 & 1 & \\
\hline Stone Fish & 0.5 & 0.5 & 1 & 1 & \\
\hline Bivalves & 2 & 1 & 2 & 1 & \\
\hline Sea Anemones & 0.5 & 0.5 & 1 & 1 & \\
\hline
\end{tabular}

reproduction. The corals broadcast their reproductive material, these reproduction material are at the mercy of bottom currents. Larvae of corals and other benthic communities can travel hundreds of kilometers away from their spawning grounds powered by sea currents, the intensity of waves varies with the south-west and north-east monsoon. During the summer monsoon, when the sea is turbulent and turbid due to intensive wind forcing, the average wave period is approximately $8 \mathrm{sec}$. This can result in the random distribution of larval settlements to scatter in large area on rocks and other substrates that are conducive platforms to grow to form patchy colonies. The subsurface currents can dislodge and destabilize rocky substrates on which budding corals establish themselves. The Department of Geology, University of Karachi who also maintain a fossilized corals repository of the Churna Island, observed that the corals from Churna Island were once more diversified than the recent ones. The reason for deterioration of present day corals of Churna waters may be due to high turbidity from floods of Hub River during the SW monsoon period. Now with the construction of Hub Dam and reduction of suspended sediment load, a better growth of corals can be foreseen. The bottom substrate is mostly sedimentary rocks (mudstone) that are easily broken by strong wave action. Attached coral are destroyed by broken rocky fragments. There is rubble coarse sand and silt on the bottom that hampers settlement of a reef structure [5]. In order to encourage and facilitate coral growth and development, environmentally conducive artificial substrate must be introduced.

The marine macro algae get shelter and food (in the form of nutrients from captured plankton) from the polyp, while the polyp also gets some food in return from the algae via photosynthesis (turning light energy from the sun into food). This photosynthesis means algae need sunlight to live, and this is why tropical corals only grow where the sea is shallow and clear. Living corals have been observed by divers between the Cape Monze and Churna Island. Here the substrate is limestone. The water temperature does not drop below $20^{\circ} \mathrm{C}$ and water turbidity is much lower than anywhere along the Pakistan coast except in monsoons for a few weeks caused by the monsoon floods in the Hub River. Most coastal marine species live in seawater temperature range between $24-27^{\circ} \mathrm{C}$. Corals are sensitive to seawater temperature changes if the water temperature is too high over extended period, coral bleaching occurs. Global warming has already led to increased levels of coral bleaching. Increased seawater temperature in coastal puts a stress and increases the mortality due to bacterial degradation of organic matter and greater demand for oxygen in the water column. The near shore water has a high oxygen concentration and it drops sharply from $4 \mathrm{ml} / \mathrm{l}$ near the shore to $1 \mathrm{ml} / \mathrm{l}$ at a distance of $25 \mathrm{~km}$ towards the sea. The near shore oxygen distribution indicates an Mehran University Research Journal of Engineering and Technology, Vol. 39, No. 2, April 2020 [p-ISSN: 0254-7821, e-ISSN: 2413-7219] 
upward sloping of the oxygen minimum layer [9]. Poor dissolved oxygen condition impact productivity of plankton, shrimps, fish and coral communities. High suspended sediments can 'smother' corals by depriving them of the light needed to survive. Similarly, the destruction of mangrove forests, which normally trap large amounts of sediment, has exacerbated the problem. Tropical coral polyps have small algae, or zooxanthellae, growing inside them. The algae also give corals their color. If the algae become stressed, such as if the water temperature becomes too high, they leave the polyp. Corals are known to be indicator of Climate change; coral bleaching occurs due to above normal seawater temperature. Negative impacts of high temp and coral bleaching phenomenon due to higher temp impacts cannot be avoided in terms of reef ecosystems along Makran Coast, as increase in temperature due to climate change is predicted to increase in frequency and severity in the coming decades [11].

Corals are biologically productive areas that support exotic tropical fish. Coral reefs are vital to coastal fisheries [12]. Tropical Coral reefs can grow upwards at rates of 1-100 $\mathrm{cm} /$ year. Coral provide spawning, nursery, shelter and feeding areas for a large variety of organisms, including economically important crustaceans (e.g. shrimps, spiny lobsters and crabs) and cephalopods (e.g. octopus, squids and cuttlefish) and thus providing revenue for local communities as well as national fishing fleets. Coral may provide micro ingredients and raw materials for the pharmaceutical industry. Reef structures also play an important role in disrupting the wave energy and act as natural breakwaters, which minimize or break the power of the waves increase damage and erosion during storms, and storm surges [13].

\subsection{Management Strategies for Coral}

People and communities rely on these resources so it is often the social, economic, or political aspects of coral reef management that drive decisions. Coral reef management strategies that seek to engage and should actively involve communities and the cooperate sector; engagement of all other stakeholder will ultimately be most effective. It is suggested that offshore high density coral areas should be demarcated and declared as a zones of aesthetic value and an area of special scientific interest. Continuous monitoring of corals using scientific survey methods should be employed [14]. While ecotourism may be encouraged, exploitation of corals for ornamental usages by locals, divers and all stake holders must be discouraged from exploiting corals.

Activities related to social science, education and, community engagement are critical, a multidisciplinary approach for the conservation of corals must also include on-the-ground management actions:

- biophysical monitoring,

- applied research,

- modeling,

- socioeconomic research,

- enforcement,

- Capacity building,

- Develop artificial substrate to facilitate Coral growth

- Provide a foundation for spiritual, scientific, educational, recreational, and visitor opportunities, all of which must be environmentally and culturally compatible.

\subsection{Conditions that Facilitate Coral Growth}

Biological resources are renewable and can even increase with proper management techniques. It is suggested that a breakwater wall be constructed to protect the budding coral from excessive waves and water current to prevent destabilizing of coral substrates.

- The breakwater wall will facilitate in dissipating the potential energy generated by the waves and currents.

- Artificial substrate must be encouraged to further facilitate the growth and development of Corals in the area

- In order to encourage and facilitate coral growth and development, conducive artificial substrate must be introduced in shallow calm waters. 
- Artificial substrates once immersed in seawater quickly develop bacterial slime (in less than a week) on the substrate surface. The bacterial slime acts as food and attracts coral larvae settle on it and grow [15].

Appropriately placed and a well-managed MPAs are effective tools to protect and restore coral reef ecosystems-particularly when combined with other management strategies, such as integrated coastal management and ecosystem-based fisheries management. Securing coastal livelihood of coastal fishing villages is essential; this can be achieved by engaging with indigenous and local communities and other stakeholders to communicate the benefits of coral reef conservation strategies, the replenishment of fisheries stocks and communities' economy. If properly managed, Coral reefs can yield around 15 tons of fish and other seafood per square kilometer each year [16]. Coral may provide micro ingredients and raw materials for the pharmaceutical industry.

International wildlife Conservation organizations such as the IUCN Mangroves for the Future (MFF) have a coral conservation component associated with program. WWF Wetlands coral reef program was initiated. The GEF (Global Environment Facility) small grants facility in Pakistan has also initiated a program for conservation of Biodiversity. As part of the CSER (Cooperate Social Environmental Responsibility) the upcoming multimillion dollar companies can partner with WWF, IUCN, GEF and the local community to develop projects to conserve Churna Island Coral and Benthic Marine Biodiversity programs.

\section{CONCLUSION}

Coral reefs are biologically rich zones of coastal areas it vital to coastal fisheries. Churna Island support variety of $\mathrm{MBI}$, marine macro and meiofauna. Budding coral communities were observed at the sedimentary rock of Churna in patches, and showed a random distribution behavior all along the area. T-test shows that the two coral sampling location $\mathrm{C}-1$ and $\mathrm{C}$ 2 were not significantly different $(p>0.1035)$ at 0.05 level. Species diversity H' (0.845-1.176) and evenness J' (0.962-0.937) were calculated, the values indicate that the coral species were evenly (J') distributed and did not show any significant variation in the area including the major MBI taxonomic groups identified and mean abundance. The bottom substrate was observed to be mostly composed of sedimentary rocks (mudstone) that are easily broken by strong wave action. Attached coral are destroyed by broken rocky fragments. Appropriately placed and a well-managed MPAs are effective tools to protect and restore coral reef ecosystems-particularly when combined with other management strategies, such as integrated coastal management and ecosystem-based fisheries management.

\section{ACKNOWLEDGMENT}

The authors gratefully acknowledge the Hub Power Company Limited, and Hagler Bailly (Pvt.) Limited, Pakistan, for allowing us to use the archived information from the ESIA Public Hearing Report 2015

\section{REFERENCES}

[1] UN-ESCAP, "Coastal Environmental Management Plan for Pakistan, Report, 1996.

[2] Pakistan Wetlands Program, "Discovery of Coral Reefs in Gwader", Ministry of Environment Report, 2013.

[3] Raza, A.S., Shaukat, S., Perveen, R., and Hussain, R., "Current Status of Coral Research in Pakistan", International Journal of Fauna and Biological Studies, Volume 1, No. 6, pp. 105-107, 2014.

[4] Hagler Bailly ESIA Report on 660 MW HUBCO Coal Fired Plants, 2015.

[5] Ali, S.I., and Memon G.D., "Geology of the Pakistan Coast and Its Influence on Corals, Oysters and Mangroves", Proceedings of The Arabian Sea - Living Marine Resources and the Environment, Thompson and Tirmizi, pp. 575-585, 1995.

[6] WWF Global, "Coral Reefs: Tropical Corals Website", 2017.

[7] Sawall, Y., Kürten, B., Hoang, B.X., Sommer, U., and Wahl, M., "Coral Communities, in Contrast to Fish Communities, Maintain a High Assembly Similarity along the Large Mehran University Research Journal of Engineering and Technology, Vol. 39, No. 2, April 2020 [p-ISSN: 0254-7821, e-ISSN: 2413-7219] 
Latitudinal Gradient along the Saudi Red Sea Coast", Journal of Ecosystem and Ecography, Volume 3, No. 4, pp. 1-7, 2014.

[8] Emma, F.C., Schoepf, V., Peter, J.M., Leonardo, A.H., Rodolfo-Metalpa, R., and David, J.S., "The Future of Coral Reefs Subject to Rapid Climate Change: Lessons from Natural Extreme Environments", Frontiers in Marine Science, Volume 2, February, 2018.

[9] Terence, P.T.N., Martin, C.F.C., Kevin, K.Y.H., Gilbert, C.S.L., Kennethm M.Y.L., and Gray, A.W., "Hong Kong's Rich Marine Biodiversity: The Unseen Wealth of South China's Megalopolis", Marine Biodiversity Records, Volume 26, No. 1, pp. 23-36, 2017.

[10] coralsoftheworld.org/page/overview-ofcoral-taxonomy/

[11] Chou, L.M., Huang, D., Tan, K.S., Toh, T.C., Goh, B.P.L., and Tun, K. "World Seas: An Environmental Evaluation", $2^{\text {nd }}$ Edition, $p$. 539-558, Elsevier, Singapore, 2019.

[12] Brandhorst. W., "Demersal Fish Resources available for the Expansion and Development of Marine Fishery of Pakistan", Proceedings of National Seminar on Policy \& Planning, Marine Fishery Department, 1994.
[13] Foster, T., and Gilmour, J.P., "Seeing Red: Coral Larvae are Attracted to Healthy-Looking Reefs", Inter-Research MEPS, Volume 559, pp. 65-71, 2016.

[14] UN Environment, ISU, ICRI and Trucost, "The Coral Reef Economy: The Business Case for Investment in the Protection", Preservation and Enhancement of Coral Reef Health, pp. 36, 2018.

[15] Glas, B., Hernd, G.J., and Frade, P.R., "The Microbiome of Coral Surface Mucus has a Key Role in Mediating Holobiont Health and Survival Upon Disturbance", International Society of Microbial Ecology Journal, Volume 10, pp. 2280-2292, 2016.

[16] https://wwf.panda.org/our_work/oceans/ coasts/coral_reefs/coral_importance/ 